\title{
THE ROLE OF PRAXEOLOGICAL PRINCIPLES IN SHAPING COMPETENCES OF LOCAL GOVERNMENTS
}

\author{
Magdalena Kisata*
}

\begin{abstract}
Local governments act based on and within legal boundaries. They realize objectives which stem from law as well. In order for law to facilitate the actual realization of specific objectives, when designing and executing it, a rational legislator ought to take into account praxeological principles. The principles influence the division of tasks and allocation of competences to proper local government bodies. As a result, they contribute to their efficient operation, shape structures the bodies function in, and determine the ways these structures operate in.
\end{abstract}

Keywords: praxeology, principles of praxeology, efficiency

\section{INTRODUCTION}

Since local governments constitute structures which act based on and within legal boundaries, and form bodies executing particular universally binding regulations, tasks and competences, praxeological principles contributing to the realization of local governments' objectives cannot be disregarded in the structures' operations. Due to the fact that the administration is obliged to act on the basis of legal norms, a reference to praxeological principles in the context of the administration's operations is valid in

* PhD, Department of Administration Studies, Faculty of Law, Canon Law and Administration, The John Paul II Catholic University of Lublin, kisala@kul.lublin.pl. 
case a need for isolating the principles from legal regulations or referring these to the regulations arises. When creating a law, a rational legislator ought to take into consideration elements which facilitate operations of local government bodies.

A complex character of tasks and competences of local governments may result in these being evaluated against different criteria, including praxeological ones. If the interpretation of law is to be based upon the principle of legislators' rationality, internal cohesion of both the legislative act and the whole legal system, then, in some cases, disregard for the linguistic interpretation justifies the necessity of assigning the interpreted regulations meaning which would make these regulations the most praxeologically effective ${ }^{1}$.

\section{LEGAL PRAXEOLOGICAL PRINCIPLES}

Praxeology is a field of studies pertaining to efficiency of operations which searches for the broadest generalizations ${ }^{2}$. When attempting to establish means for achieving the efficiency, praxeology deals with 1) construing efficiency-related theses and recommendations, general principles and conditions of operations. Practical recommendations and directives are derived from these, 2) systematizing and specifying ideas and terminology encompassing the issue of operations' efficiency ${ }^{3}$. When praxeological principles are taken into consideration, some of the principles are transformed into legal norms and become principles of administrative law ${ }^{4}$.

Therefore, praxeological principles constitute "objective regularities"5 which refer to or may be referred to the organization of public administra-

${ }^{1}$ Wyrok WSA w Warszawie z 17 maja 2011 r., III SA/Wa 2759/10.

2 Tadeusz Kotarbiński, „Dzieła wszystkie, Prakseologia”, Część II, Wrocław: Zakład Narodowy im. Ossolińskich, 2003, p. 111.

${ }^{3}$ Konstanty Piłejko, „Prakseologia - nauka o sprawnym działaniu”, Warszawa: PWN, 1976, pp. 19-21.

" Jerzy Supernat, „Odesłania do zasad prakseologicznych w prawie administracyjnym”, Wrocław: Wydawnictwo Uniwersytetu Wrocławskiego, 1984, pp. 21, 27.

${ }^{5}$ Ibidem, p. 4. 
tion, including local governments. They are also incorporated into legal regulations, and constitute a "contribution of ergology i.e. the science of evaluating various spheres of human activity with regards to efficiency" which law refers to. They influence the division of tasks and allocation of competences among proper local government bodies along with the shape of these structures, and determine ways they operate in.

They operate on the verge of administrative law and administrative sciences- the science of administration, theory of organizations, theory of decision-making. These are praxeological principles of "good administration" or ""proper operation"

The following can be enumerated as belonging to legal means of application of praxeological principles of administrations' organization:

1. Expressing praxeological principles directly in the language of the law.

2. Shaping administrations' organization in regulations so that they encompass praxeological principles.

3. Referring to praxeological principles by means of provisions of cross-reference.

In practice, meeting particular legal and organizational solutions may be troublesome due to the fact that one regulation will express two of the above means ${ }^{8}$. Moreover, praxeological principles of administrative law formulated in the doctrine are of various character due to their hierarchy and extraction criteria.

The following may be considered as elements of legal praxeological principles which may be referred to the operation of local governments: decentralization of public authorities, subsidiarity, competence, monocracy and collegiality ${ }^{9}$, organizational flexibility, obligation for public administration bodies to cooperate ${ }^{10}$.

${ }^{6}$ Ibidem, p. 4.

7 Jan Zimmermann, „Prawo administracyjne”, Warszawa: Wolters Kluwer, 2012, p. 101 .

${ }^{8}$ Jerzy Supernat, „Odesłania do zasad prakseologicznych w prawie administracyjnym”, Wrocław: Wydawnictwo Uniwersytetu Wrocławskiego, 1984, p. 22.

${ }^{9}$ Ibidem, p. 33.

${ }^{10}$ Stanisław Biernat, „Działania wspólne w administracji państwowej”, Wrocław: Zakład Narodowy im. Ossolińskich, 1979. 
The principle of decentralization determines the distribution of competences so that operations bring a desired result in the form of local society's needs being fully and optimally satisfied via the application of resources a local government body has at disposal. Therefore, the capacity of the body on a particular hierarchy level, the community's requirements, and the state's interests need to be evaluated. When designing a particular administrative structure, the legislator must decide upon the scope of law to be assigned to the individual nodes in the administrative structure. Therefore, in particular cases, the legislator may concentrate or deconcentrate in order to rationalize the structure or the realization of particular values. The legislator may change the concept of public administration and deconcentrate the scope. The process may take on the form of ministerial (vertical) or territorial (horizontal) deconcentration ${ }^{11}$. Such processes are clearly visible in the scope of public administration's departments, but also in cases when an agreement is made between a public administration and local government body.

The principle of subsidiarity is associated with decentralization, and supplements it. Based on the principle, the legislator decides upon the particular level a task ought to be executed on, and assigns competences associated with the task. Administrative decisions pertaining to citizens ought to be made on possibly the lowest level and one closest to the citizen. In addition, efficiency constitutes a criterion for decisions made on higher levels ${ }^{12}$. Therefore, the assignment of tasks and competences to a particular body will have an organizational ${ }^{13}$, and enhancing character impacting the operation of local government's bodies. In accordance with the principle of subsidiarity, a large body ought not to be assigned to realize tasks which may be realized with the same efficiency by a smaller body. Larger bodies ought to operate in areas where the size of the body gives it the capacity

${ }^{11}$ Zbigniew Cieślak, „Podstawowe instytucje prawa administracyjnego”, In: Prawo administracyjne, ed. Zygmunt Niewiadomski, Warszawa: Lexis Nexis, 2011, pp. 84-85.

12 Dariusz Milczarek, „Subsydiarność-próba bilansu”, In: Subsydiarność, ed. Dariusz Milczarek, Warszawa: Dom Wydawniczy ELIPSA, 1998, p. 319.

${ }^{13}$ Marcin Matczak, „Kompetencja organu administracji publicznej”, Kraków: Kantor Wydawniczy Zakamycze, 2004, p. 27. 
for acting more efficiently than smaller bodies would ${ }^{14}$. The division of power in accordance with subsidiarity ought to be rational and based upon efficiency ${ }^{15}$.

The principle of competence indicates a rationale behind the assignment of competences to proper bodies, and, as a consequence, it impacts the establishment of competence systems. The principle encompasses issues associated with the determination of competences, competence capacity of a body, and observance of competences. The praxeological character of the principle is linked with the competence capacity. When evaluating the capacity, two aspects ought to be considered: the first, the relationship between the body's competence scope and the scope of operations, which is evaluated based on the body's position in public administration's structure, and the second, whether the structure of a particular body and the distribution of tasks among its employees are sufficient for competences assigned to the body to be realized ${ }^{16}$.

To summarize the principles and their role in shaping competence systems in local governments, it can be said that decentralization and subsidiarity exert impact upon systems of competences between public administration and local government bodies, and between individual local government bodies as well. A proper competence system based on the principles is to ensure public and public administration's tasks are executed, and competences distributed among various bodies. Such distribution is associated with the efficiency of operation and with needs of the community being satisfied. The principle of competence pertains primarily to competences being determined properly and a particular body being assigned to them.

Principles of monocracy and collegiality pertain to the composition and functioning of a public administration's body and methods of operations ${ }^{17}$. A monocratic body performs operations and realizes competences independently and bears full responsibility for these. Therefore, the prin-

${ }^{14}$ Francois Saint-Ouen, „Podział władzy w demokracji europejskiej”, Samorząd Terytorialny 6(1991): 4.

${ }^{15}$ Bogdan Dolnicki, „Samorząd terytorialny”, Warszawa: Oficyna a Wolters Kluwer business, 2009, p. 25.

${ }^{16}$ Adam Jaroszyński, „Wpływ przekształceń administracji socjalistycznej na pozycję prawną obywatela”, Warszawa: Państwowe Wydawnictwo Naukowe, 1977, p. 96.

${ }^{17}$ Zbigniew Leoński, „Nauka administracji”, Warszawa: C.H. Beck, 2010, p. 67. 
ciple denotes that there is only one person competent for undertaking a particular task. On the other hand, collegiality, pertaining to a body's structure, denotes a collective structure and decisions made jointly. As a consequence, the body operating on the basis of this principle does not require a collective structure (it can be a monocratic body). However, in such cases, before a final decision is made, the body requests an opinion of a council ${ }^{18}$. In the structure of public administration, both monocracy and collegiality ought to be well-balanced due to the fact that they supplement each other and impact the efficiency of state systems ${ }^{19}$. When making a reference between these principles and shaping competence systems in local governments, the way competences are realized by these bodies ought to be considered. When assigning competences to a monocratic body, the legislator gives a greater autonomy and, at the same time, responsibility for decisions made. Therefore, these principles will be associated with the way competences are realized in the framework of competence systems.

In relation to local governments, the principle of obligation of public administration bodies to cooperate denotes the obligation to undertake lawful action. An example of such an obligation is the Bill on Commune Government of $8^{\text {th }}$ March $1990^{20}$ and the option of establishing a union of communes set in it ${ }^{21}$. The bill coming into force results in competence systems being established on the day the statute of the union is signed. The praxeological character of the principle is expressed in the objective the union is set with, i.e. joint execution of public tasks, which results in needs of the community being satisfied swiftly and more efficiently due to the cooperation of bodies obliged by the legislator to act together.

The principle of organizational flexibility refers to the composition of administrative structure of local governments. Its role in shaping local governments' competence systems is not associated with determining the

${ }^{18}$ Zbigniew Cieślak, „Praktyka organizowania administracji publicznej”, Warszawa: Wydawnictwo Difin S.A., 2004, pp. 31-34.

${ }^{19}$ Bogdan Dolnicki, „Elementy prakseologiczne w strukturze i działaniu administracji publicznej”, In: Współzależność dyscyplin badawczych w sferze administracji publicznej, eds. Stanisław Wrzosek, Michał Domagała, Jan Izdebski, Tadeusz Stanisławski, Warszawa: C.H. Beck, 2010, p. 517.

${ }^{20}$ Uniform text, Journal of Laws of 2016, item 446 as amended.

${ }^{21}$ Article 64 sec. 4. 
bodies' competences and their scope, but revolves around the organization of local governments' structure within legal boundaries ensuring its efficiency and capacity for executing tasks and competences.

In accordance with the praxeological concept of public administration's organization, in macro scale, it is composed of several diverse organizational bodies connected in the framework of individual systems impacting one another and operating on the basis of legal regulations, and contributing to the success of the whole system of public administration. The organization of the administration may be also viewed in micro scale pertaining to the operation of the institution as an organizational unit composed of particular elements, such as sections, departments, and clerks, constituting a particular whole, whose individual elements contribute to the success of the whole itself ${ }^{2}$.

\section{THE PRINCIPLE OF EFFICIENCY}

The composition of an organizational structure depends on several factors, especially the objective it is designed for, constituting elements, resources, and surrounding environment. Operations of the structure should be efficient, i.e. it ought to be:

1) Effective- aiming to achieve objectives;

2) Profitable- a positive relationship between results and costs of operation;

3) Economic- results of operations surpass associated costs;

4) Organized on the basis of the fewest possible elements contributing to the achievement of results, i.e. it ought to be simple and straightforward;

${ }^{22}$ Zbigniew Cieślak, „Praktyka organizowania administracji publicznej”, Warszawa: Wydawnictwo Difin S.A., 2004, pp. 24-25, Sławomir Fundowicz, „Prakseologiczne uwarunkowania prawa administracyjnego”, In: Współzależność dyscyplin badawczych w sferze administracji publicznej, eds. Stanisław Wrzosek, Michał Domagała, Jan Izdebski, Tadeusz Stanisławski, Warszawa: C.H. Beck, 2010, p. 419. 
5) Clean- lack of negatives in operation, i.e. those incompatible with objectives of the organizational structure;

6) Comprehensive- taking both significant matters and side issues conforming with main objectives into consideration;

7) Accurate- recreating the model as accurately as possible;

8) Rational- adjusted to circumstances ${ }^{23}$.

According to W. Dawidowicz, operations are efficient if they lead to a particular objective requiring the smallest possible effort and resources. An efficient operation is effective and swift ${ }^{24}$.

The principle of efficiency may be considered as the principle of both administrative law and the field of public administration. As the principle of law, it introduces a normative obligation for administrations' efficient operation $^{25}$. The principle is manifested in regulations pertaining to: 1) supervision of local governments - in case no prospects of swift improvement are observed and lack of efficiency in actions by communes, districts and provinces is prolonged, a receivership may be established, 2) the necessity of ensuring efficiency in registering unions of communes, districts, district-commune unions, and announcing acts and information, 3) efficient manner of selecting senior fellows in commune board. Efficiency will also be associated with ensuring citizens receive fundamental social benefit ${ }^{26}$, with efficiency and effectiveness of administrative decisions, effectiveness of law laid by the administration ${ }^{27}$. Moreover, the efficiency of administration is manifested in operating within legal boundaries and in accordance with expectations of the public ${ }^{28}$.

${ }^{23}$ Jan Zieleniewski, „Organizacja zasobów ludzkich”, Warszawa: PWN, 1967, pp. 223-240.

${ }^{24}$ Wacław Dawidowicz, „Zagadnienia ustroju administracji państwowej w Polsce”, Warszawa: Państwowe Wydawnictwo Naukowe, 1970, p. 53.

${ }^{25}$ Zbigniew Cieślak, „Praktyka organizowania administracji publicznej”, Warszawa: Wydawnictwo Difin S.A., 2004, p. 55.

${ }^{26}$ Zbigniew Cieślak, „Praktyka organizowania administracji publicznej”, Warszawa: Wydawnictwo Difin S.A., 2004, p. 59.

${ }^{27}$ Jan Łukasiewicz, „Nauka administracji. Wstęp do teorii administracji”, Przemyśl: Wyższa Szkoła Administracji i Zarządzania w Przemyślu, 1997, p. 19.

${ }^{28}$ Jan Łukasiewicz, „Prawne uwarunkowania skuteczności działań administracji państwowej”, Lublin: UMCS, 1990, p. 103. 
J. Supernat postulates the principle of efficiency to be considered as a fundamental rule of law of praxeological character, in a directive and legally binding sense ${ }^{29}$.

The efficiency of local governments is determined by numerous factors which can be classified as substantial and personal. The former include: a) organizational structures of administrative bodies, b) territorial division for administrative purposes, c) legal regulations regulating the organization and operations of administration, d) information systems and decisionmaking processes, e) work methods applied in administrative operations, f) organization and technique of administrative work. The latter encompass resources associated with personnel employed in local governments, e.g. qualifications of employees, HR policies, work conditions.

Effectiveness, profitableness, end economy belong to the fundamental principles of efficient operation.

Effectiveness is associated with achieving an objective understood as obtaining a result which is as close to the objective set as possible. Objectives form a hierarchical system where achieving indirect objectives leads to achieving ultimate ones. Objectives change. Therefore, local governments' efficiency may be assessed by evaluating the capacity for adapting its functions, organization and methods to such changing conditions ${ }^{30}$.

It is law that designs efficiency. However, the law is not sufficient to achieve actual efficiency ${ }^{31}$. The efficiency may be considered in thee understandings. In a strict sense, the efficiency denotes the relationship between the efficiency of legal norms and objectives set by the legislator. The second understanding assesses whether and to what degree results of the application of law are convergent with the legislator's objectives. Finally, the efficiency can be understood as the way particular legal decisions are executed ${ }^{32}$.

${ }^{29}$ Jerzy Supernat, „Odesłania do zasad prakseologicznych w prawie administracyjnym”, Wrocław: Wydawnictwo Uniwersytetu Wrocławskiego, 1984, p. 46.

${ }^{30}$ Marcin Jełowicki, „Nauka administracji: zagadnienia wybrane”, Warszawa: PWN, 1987, p. 260.

${ }^{31}$ Jan Łukasiewicz, „Prawne uwarunkowania skuteczności działań administracji państwowej”, Lublin: UMCS, 1990, p. 23.

32 Jerzy Wróblewski, „Skuteczność prawa i problemy jej badania”, Studia Prawnicze 1-2 (1980): 6. 
The efficiency of law may also be considered in a broad or narrow sense. In the broad sense, it denotes the compatibility of social results of enforcement of a particular legal norm with the legislator's intentions. In the narrow sense, it pertains to the behavior of the addressee of the norm in relation to the model behavior described in the norm itself ${ }^{33}$.

Legality constitutes the limit of efficiency. It also constitutes the fundament of operations for a system of administration. Therefore, achieving objectives based on praxeological principles disregarding legality constitutes a breach of law. Praxeological principles regulate law, but bind administration only when they are included in the positive law ${ }^{34}$, and when the legislator refers to them and indicates their applicability.

In relation to local governments' operations, profitableness pertains to general benefits compared with costs of the public, and tangible benefits (undertakings, tasks) compared with costs of these undertakings $s^{35}$. A task is profitable if the outcome surpasses costs, and is unprofitable when costs surpass the results and generates a tangible loss ${ }^{36}$.

Economy of public administrations' operations is associated with costs of the state's administrative operations, e.g. costs of undertakings, tasks and actions, upkeep of administrative system, social costs, i.e. costs borne by the public, costs associated with administrative operations ${ }^{37}$. The economy is associated with permanent pursuit of improvement in the relationship between results and expenditures- not only the financial ones, but also, broadly, those regarding public interests and the most effective way of satisfying needs ${ }^{38}$.

${ }^{33}$ Maria Borucka-Arctowa, „O społecznym działaniu prawa”, Warszawa: PWN,1967, p. 11.

${ }^{34}$ Jan Łukasiewicz, „Prawne uwarunkowania skuteczności działań administracji państwowej”, Lublin: UMCS, 1990, p. 49.

${ }^{35}$ Marcin Jełowicki, „Nauka administracji: zagadnienia wybrane”, Warszawa: PWN, 1987, p. 261.

${ }^{36}$ Konstanty Piłejko, „Prakseologia - nauka o sprawnym działaniu”, Warszawa: PWN, 1976 , p. 141.

${ }^{37}$ Marcin Jełowicki, „Nauka administracji: zagadnienia wybrane”, Warszawa: PWN, 1987, p. 261.

${ }^{38}$ Konstanty Piłejko, „Prakseologia - nauka o sprawnym działaniu”, Warszawa: PWN, 1976 , p. 140. 
Regulation of all operations of the administration is neither advisable nor possible. Therefore, in individual cases, the legislator resigns from direct regulation and assigns particular normative sense to regulations formulated outside law, by referring to them. However, due to the reference, these do not obtain the character of legal norms, but retain the character of external regulations ${ }^{39}$. Ignoring such regulations constitutes a breach of $\operatorname{law}^{40}$.

As a consequence, the structure of local governments is determined by numerous factors. Tasks set for public administration determine its organizational structure, and proper establishment of objectives determines its suitable organization and efficient operation ${ }^{41}$. According to J. Eukasiewicz, the system and organization establish a mutual context ${ }^{42}$, because the norm and organization in administration overlap ${ }^{43}$. Consequently, norms of administrative law pertain to the organization, and organizational requirements shape legislative process in the field ${ }^{44}$. Therefore, a particular organizational structure facilitates the execution of tasks and competences.

Apart from shaping structures, proper assignment of tasks and competences, and their execution by appropriate units of local governments, constitute the main efficiency factor. Jointly, these determine the structure of administration. Legal establishment of tasks and competences of

${ }^{39}$ Jerzy Supernat, „Odesłania do zasad prakseologicznych w prawie administracyjnym”, Wrocław: Wydawnictwo Uniwersytetu Wrocławskiego, 1984, pp. 49, 72-73.

${ }^{40}$ Jerzy Starościak, „Podstawy prawne działania administracji”, Warszawa: Wydawnictwo Prawnicze, 1957, p. 116.

${ }^{41}$ Zbigniew Cieślak, „Praktyka organizowania administracji publicznej”, Warszawa: Wydawnictwo Difin S.A., 2004, p. 23.

${ }^{4}$ Jan Łukasiewicz, „Prawne uwarunkowania skuteczności działań administracji państwowej”, Lublin: UMCS, 1990, p. 98.

${ }^{43}$ Jan Łukasiewicz, Stanisław Wrzosek, „Relacje pomiędzy naukami o zarządzaniu a naukami o administracji”, In: Zastosowanie nauk o zarządzaniu w organizacjach gospodarczych i administracji publicznej, eds. Magdalena Kisała, Wojciech Wytrążek, Radom: Wyższa Szkoła Handlowa w Radomiu, 2008, p. 131.

${ }^{44}$ Jan Łukasiewicz, „Słowo o aktualności prakseologicznej płaszczyzny badań nad administracją publiczną”, In: Współzależność dyscyplin badawczych w sferze administracji publicznej, eds. Stanisław Wrzosek, Michał Domagała, Jan Izdebski, Tadeusz Stanisławski, Warszawa: C.H. Beck, 2010, p. 388. 
administration determines the position of the bod $y^{45}$. The scope of tasks and competences of administrative bodies must reflect the current technical knowledge ${ }^{46}$. Moreover, the duty to act stems not only from norms regarding competences and tasks, but also from reference norms, e.g. praxeological principles ${ }^{47}$.

At present, administration's legal authorization to act is insufficient. However, it will become sufficient when accompanied by the sense of efficiency of activities and acceptance of administrations' actions ${ }^{48}$. Competences being determined accurately and properly distributed among various bodies enable efficiency and effectiveness of actions to be maximized and legality ensured ${ }^{49}$.

\section{CONCLUSIONS}

In conclusion, the principles discussed above may be classified in three groups: 1) pertaining to the establishment and assignment of competences among various local government bodies, 2) pertaining to structures these bodies function in, and execute their tasks and competences in, and 3) pertaining to the construction of the bodies themselves, which exerts impact upon efficiency and effectiveness of their operations.

Legal principles of praxeological character constitute principles influencing the shape and content of competence systems. Competences must originate from a clear legal regulation. The scope of competences is also

${ }^{45}$ See Jan Łukasiewicz, „Prawne uwarunkowania skuteczności działań administracji państwowej”, Lublin: UMCS, 1990, p. 91.

${ }^{46}$ Jan Borkowski, „Podmioty administracji publicznej a przemiany ustrojowe”, In: Podmioty administracji publicznej i prawne formy ich działania, Studia i materiały z Konferencji Naukowej Poświęconej Jubileuszowi 80-tych urodzin Profesora Eugeniusza Ochendowskiego, Toruń: Dom Organizatora, Toruń, 2005, p. 62.

${ }^{47}$ Małgorzata Ofiarska, „Formy publicznoprawne współdziałania jednostek samorządu terytorialnego”, Warszawa: C.H. Beck, 2008, p. 185.

${ }^{48}$ Irena Lipowicz, „Istota administracji”, In: Prawo administracyjne, ed. Zygmunt Niewiadomski, Warszawa: Lexis Nexis, 2007, p. 36.

49 Jan Łukasiewicz, „Prawne uwarunkowania skuteczności działań administracji państwowej", Lublin: UMCS, 1990, p. 95. 
determined by legal regulations. Remaining praxeological principles will be of organizational character, i.e. will pertain to the construction of organizational structures the local government bodies will execute their competences in. If legal regulations incorporate praxeological principles, tangible efficiency of law and administrative bodies' operations will be ensured.

\section{REFERENCES:}

Biernat, Stanisław. 1979. „Działania wspólne w administracji państwowej”. Wrocław: Zakład Narodowy im. Ossolińskich.

Borkowski. Jan. 2005. „Podmioty administracji publicznej a przemiany ustrojowe". In: Podmioty administracji publicznej i prawne formy ich działania. Studia i materiały z Konferencji Naukowej Poświęconej Jubileuszowi 80-tych urodzin Profesora Eugeniusza Ochendowskiego, 62. Toruń: Dom Organizatora.

Borucka-Arctowa, Maria. 1967. „O społecznym działaniu prawa”. Warszawa: PWN.

Cieślak, Zbigniew. 2011. „Podstawowe instytucje prawa administracyjnego”. In: Prawo administracyjne, ed. Zygmunt Niewiadomski, Warszawa: Lexis Nexis.

Cieślak, Zbigniew. 2004. „Praktyka organizowania administracji publicznej”. Warszawa: Wydawnictwo Difin S.A.

Dawidowicz, Wacław. 1970. „Zagadnienia ustroju administracji państwowej w Polsce". Warszawa: Państwowe Wydawnictwo Naukowe.

Dolnicki, Bogdan. 2010. „Elementy prakseologiczne w strukturze i działaniu administracji publicznej”. In: Współzależność dyscyplin badawczych w sferze administracji publicznej, eds. Stanisław Wrzosek, Michał Domagała, Jan Izdebski, Tadeusz Stanisławski, Warszawa: C.H. Beck.

Dolnicki, Bogdan, 2009. „Samorząd terytorialny”. Warszawa: Oficyna a Wolters Kluwer business.

Fundowicz, Sławomir. 2010. „Prakseologiczne uwarunkowania prawa administracyjnego". In: Współzależność dyscyplin badawczych w sferze administracji publicznej, eds. Stanisław Wrzosek, Michał Domagała, Jan Izdebski, Tadeusz Stanisławski, 419. Warszawa: C.H. Beck.

Jaroszyński, Adam. 1977. „Wpływ przekształceń administracji socjalistycznej na pozycję prawną obywatela”. Warszawa: Państwowe Wydawnictwo Naukowe. 
Jełowicki, Marcin. 1987. „Nauka administracji: zagadnienia wybrane”. Warszawa: PWN.

Wróblewski, Jerzy. 1980. „Skuteczność prawa i problemy jej badania”. Studia Prawnicze 1-2.

Kotarbiński, Tadeusz. 2003. „Dzieła wszystkie. Prakseologia”. Część II. Wrocław: Zakład Narodowy im. Ossolińskich.

Leoński, Zbigniew. 2010. „Nauka administracji”. Warszawa: C.H. Beck.

Lipowicz, Irena. 2007. „Istota administracji”. In: Prawo administracyjne, ed. Zygmunt Niewiadomski, 36. Warszawa: Lexis Nexis.

Łukasiewicz, Jan. 1997. „Nauka administracji. Wstęp do teorii administracji”. Przemyśl: Wyższa Szkoła Administracji i Zarządzania w Przemyślu.

Łukasiewicz, Jan. 1990. „Prawne uwarunkowania skuteczności działań administracji państwowej”. Lublin: UMCS.

Łukasiewicz, Jan, Wrzosek, Stanisław, 2008. „Relacje pomiędzy naukami o zarządzaniu a naukami o administracji”. In: Zastosowanie nauk o zarządzaniu w organizacjach gospodarczych i administracji publicznej, eds. Magdalena Kisała, Wojciech Wytrążek, Radom: Wyższa Szkoła Handlowa w Radomiu.

Łukasiewicz, Jan. 2010. „Słowo o aktualności prakseologicznej płaszczyzny badań nad administracją publiczną”. In: Współzależność dyscyplin badawczych w sferze administracji publicznej, eds. Stanisław Wrzosek, Michał Domagała, Jan Izdebski, Tadeusz Stanisławski, Warszawa: C.H. Beck.

Matczak, Marcin. 2004. „Kompetencja organu administracji publicznej”. Kraków: Kantor Wydawniczy Zakamycze.

Milczarek, Dariusz. 1998. „Subsydiarność-próba bilansu”. In: Subsydiarność, ed. Dariusz Milczarek, Warszawa: Dom Wydawniczy ELIPSA.

Ofiarska, Małgorzata. 2008. „Formy publicznoprawne współdziałania jednostek samorządu terytorialnego". Warszawa: C.H. Beck.

Piłejko, Konstanty. 1976. „Prakseologia - nauka o sprawnym działaniu”. Warszawa: PWN.

Saint-Ouen, Francois, 1991. „Podział władzy w demokracji europejskiej”. Samorząd Terytorialny 6.

Starościak, Jerzy. 1957. „Podstawy prawne działania administracji”. Warszawa: Wydawnictwo Prawnicze.

Supernat, Jerzy. 1984. „Odesłania do zasad prakseologicznych w prawie administracyjnym". Wrocław: Wydawnictwo Uniwersytetu Wrocławskiego.

Zieleniewski, Jan. 1967. „Organizacja zasobów ludzkich”. Warszawa: PWN. Zimmermann, Jan. 2012. „Prawo administracyjne”. Warszawa: Wolters Kluwer. 